\title{
Composition of Mabí Ingredients, Mabí Prepared by the Conventional Method and by Controlled Fermentation'
}

\author{
Horace D. Graham and Pedro E. Laboy Zengotita ${ }^{2}$ \\ ABSTRACT
}

\begin{abstract}
Mabi bark extract used in the preparation of the beverage contains $6.1-$ $16 \%$ total soluble carbohydrates and $1.2-2.8 \%$ reducing sugars; an average of $0.34-0.77 \%$ tannins; $2.25-3.75 \%$ crude protein; and the minerals $\mathrm{P}, \mathrm{Ca}$, $\mathrm{Mg}, \mathrm{K}, \mathrm{Fe}, \mathrm{Mn}$ and $\mathrm{Na}$. Unretined sugar contained all the above-listed minerals except $P$, whereas no $P, F e$, nor $M n$ was detected in the tap water. The "pie" or fermented mabi, contributes all of the above-iisted ingredients, especially the protein. Mabi analyzed contained 2.8-3.2\% crude protein.

Mabi was prepared by the conventional method and also by inoculating sterilized ingredients with a mixture of Aerobacter aerogenes and Saccharomyces cerevisiae. In both products, ethanol, lactic and acetic acids were found, and the final pH values were similar, being 3.7 and 3.9 , respectively. Both products also contained the flavoring substances acetaldehyde, methyl and ethyl acetates, isoamyl alcohol, and acetylmethylcarbinol. Diacetyl was absent from both types.
\end{abstract}

\section{INTRODUCTION}

Many minor fermentations provide highly delightful and nourishing drinks or foods for peoples in various parts of the world. In Puerto Rico, mabi (mavi) is the prime example of such minor fermentations.

To prepare this Puerto Rican beverage, unrefined sugar, an aqueous extract of the bark of the mabi shrub and "pie" (previously fermented mabi) are mixed and allowed to ferment at $28 \pm 2^{\circ} \mathrm{C}$ for 24-48 hours. During the fermentation, flavoring substances, $\mathrm{CO}_{2}$, acids and alcohol are produced by bacteria of the Enterobacter group and a yeast Saccharomyces cerevisiae $(10,13)$.

Maximum microbial growth in any medium requires the presence of not only carbohydrates but also a nitrogen source, minerals and, in many cases, several growth factors as well. In the substrate mixture for the preparation of mabí, the sugar and bark supply the major part of the above named ingredients. The characteristic astringent taste of the beverage is due to components of the bark, most likely tannins.

No data are available on the composition of the mabí bark and there is only general information on non-carbohydrate materials in the sugar which can serve as nutrients for the fermenting microorganisms. Therefore, experiments were designed to obtain such information.

'Manuscript submitted to Editorial Board April 1, 1981.

${ }^{2}$ Professur of Chemistry, University of Puerto Rico, Mayagüez Campus; and Instructor, Division of Natural Sciences, Ponce Regional College, University of Puerto Rico, Ponce, P.R. Thanks are due to Heriberto Batiz and Eduardo Rosado of the Rum Pilot Plant, Agricultural Experiment Station, University of Puerto Rico, for their unselfish cooperation in the gas chromatographic analysis of samples of mabí. 
Reported here are data on the amount of nitrogen, tannin, mineral and soluble carbohydrates in the bark and bark extract. The mineral content of the unrefined sugar and of the water is also presented. In addition, there is presented a comparison of fermentation products in mabi prepared in the conventional manner and in mabi prepared in a controlled fermentation (10).

\section{MATERIALS AND METHODS}

All chemicals used were of reagent grade and, unless otherwise specified, were used without further purification. Tap water was used in the preparation of mabi in order to simulate the conventional practice. For the preparation of reagents distilled water was used.

Colorimetric measurements were made with a Bausch and Lomb Spectronic 20 spectrophotometer. ${ }^{3}$ Gas chromatography was done with a Hewlett Packard gas chromatograph, model 5750. Other equipment mentioned was of conventional laboratory types.

\section{PROCEDURE}

In the bark, bark extract, sugar and water, determinations were done for phosphorus, potassium, sodium, magnesium, iron, manganese and calcium. Tannins, soluble carbohydrates, reducing sugars and nitrogen were determined in the bark extract.

Nitrogen was determined by the microkjeldahl method (1). Percent crude protein was calculated as $\mathrm{N} \times 6.25$. Soluble carbohydrates were extracted as per Joslyn (5) and were determined by the phenol- $\mathrm{H}_{2} \mathrm{SO}_{4}$ method (2). Reducing sugars were determined by the alkaline copper sulfate method as outlined by Neish (11) and tannins with the FolinDenis reagent (3).

Sugars in the extract of the bark were identified by two-dimensional paper chromatography in a $n$-butanol-pyridine-water (3:1:1) and $n$-propanol-ethylacetate-water (7:1:2) system.

Phosphorus was determined colorimetrically by the ascorbic acid reduction method (John, 4). Sodium, potassium, iron, magnesium, calcium and manganese were determined by atomic absorption.

To ascertain the quality of mabi prepared by the conventional method and by controlled fermentation, analyses were made of the fermentation products. Preparation of mabi by both procedures has been described previously by Montoya and Graham, (10). Determinations were done for ethyl alcohol, sugar (sucrose), total acidity (as acetic acid) and volatile acidity (as acetic acid).

\footnotetext{
: Trade names in this publication are used only to provide specific information. Mention of a trade name does not constitute a warranty of equipment or materials by the Agricultural Experiment Station of the University of Puerto Rico, nor is this mention a statement of preference over other equipment or materials.
} 
Flavoring substances determined were acetaldehyde, methyl acetate, ethyl acetate, isoamyl alcohol, acetylmethylcarbinol and diacetyl. Fermentation acids determined were formic, acetic, lactic and succinic.

Ethyl alcohol, total sugars, total acidity and volatile acidity were determined according to the procedures outlined in the Rum Pilot Plant Manual (1969).

Flavoring substances and formic acid were determined by gas chromatography. Acetylmethylcarbinol (acetoin) was determined by the method of Landlyke and Peterson (7). Lactic acid was determined by the parahydroxydiphenyl method Neish (11). Succinic acid was determined as its dipotassium salt (14).

\section{RESULTS AND DISCUSSIONS}

Sucrose was the major sugar found in the mabí bark. Also present were glucose and fructose, reported as reducing sugars (table 1). Sucrose was calculated to be the major sugar by determining the difference between the soluble carbohydrates and the reducing sugars. Two-dimensional chromatography confirmed that the three above named sugars were present in the mabi extract. Thus, the aqueous extract of the mabí bark contributes a small amount $(0.09-0.24 \%)$ of sugar for the fermenting organisms. However, the amount of unrefined sugar added is so comparatively overwhelming (15\%) that such a contribution from the bark is negligible. The "pie" will also contribute some, since in mabi the amount of unfermented sugar is usually high $-10.6 \%$, (table 2 ).

Tannins in the aqueous extract of the bark amounted to $0.34-0.77 \%$, (table 3). Using as an analogy the taste of other fermented beverages such as wine and beer, it may be concluded that the bark tannins in the mabi drink are responsible for the astringency of the beverage.

Tannins give body and fullness of flavor to the foods in which they occur. For example, cider produced from apples with a relatively high tannin content (cider apples) has "body" and a mellow astringency. On the contrary, cider produced from so-called culinary apples tends to be insipid.

An appreciable amount of tannins in tea imparts body and a pleasing astringency to the beverage. In wine, a slight astringency because of the natural tannins in the skin and seeds of the grapes is a desirable attribute. In beer production, the hops and, according to some investigators, the malt contribute tannins which endow the final brewed product with a pleasant astringency.

New red wines contain approximately $0.2-0.3 \%$ of tannins $(6,9)$. This amount decreases drastically as the wine ages (9) probably because of oxidation of the tannins, a process which, among others, contributes to the characteristic flavor of the drink (12).

In white wines, the level of tannins is about one-tenth of that in red 
wines or about $0.02-0.03 \%$ (9). From the data obtained here, it has been calculated that the bark extract contributes $0.005-0.017 \%$ of tannins to the drink. Assuming that the bark used in preparing the mabi used as "pie", had the same concentration of tannins as the bark analyzed here, then the "pie" would contribute $0.017-0.039 \%$ of tannins. The total tannin contributed by the bark extract and the "pie" would be $0.022-0.038 \%$.

T'ABLE 1.-Sugar in aqueous extract of mabi bark extraction done at $100^{\circ} \mathrm{C}$ for 30 min expressed in terms of glucose

\begin{tabular}{|c|c|c|c|c|}
\hline \multirow{2}{*}{ Source of sample } & \multicolumn{2}{|c|}{ Soluble carbohydrates $(w / v)$} & \multicolumn{2}{|c|}{ Reducing sugar $(w / v)$} \\
\hline & Range & Average & Range & Average \\
\hline Juana Díaz & $15.8-16.2$ & I6.1 & $2.5-3.0$ & 2.7 \\
\hline Lajas & $10.2-11.4$ & 11.0 & $1.6-2.0$ & 1.9 \\
\hline Mayagüiez & $5.0-6.6$ & 6.1 & $1.0-1.5$ & 1.2 \\
\hline Ponce & $15.4-15.8$ & 15.7 & $1.5-2.5$ & 2.1 \\
\hline Yauco & $10.8-11.8$ & 11.5 & $2.0-3.5$ & 2.8 \\
\hline
\end{tabular}

TABLer 2.-Chenical analysis of mabi prepared by the conventional and by the controlled method of fermentation

\begin{tabular}{lcc}
\hline \multicolumn{1}{c}{ Subatance } & Conventional method & Controlled fermentation \\
\hline Ethyl alcohol & $1.6 \%$ & $1.2 \%$ \\
Residual sucrose & $10.6 \mathrm{~g} / 100 \mathrm{ml}$ & $12.7 \mathrm{~g} / 100 \mathrm{ml}$ \\
Total acidity (as acetic acidity) & $114 \mathrm{mg} / 100 \mathrm{ml}$ & $95 \mathrm{mg} / 100 \mathrm{ml}$ \\
Volatile acidity (as acetic acid) & $78 \mathrm{mg} / 100 \mathrm{ml}$ & $45 \mathrm{mg} / 100 \mathrm{ml}$ \\
Acetic acid & $67 \mathrm{mg} / 100 \mathrm{ml}$ & $38 \mathrm{mg} / 100 \mathrm{ml}$ \\
Lactic acid & $39 \mathrm{mg} / 100 \mathrm{ml}$ & $43 \mathrm{mg} / 100 \mathrm{ml}$ \\
Formic acid & - & - \\
Succinic acid & - & - \\
pH & 3.7 & 3.9 \\
\hline
\end{tabular}

TARLE 3,-Tannins in aqueots extract of bark of mabi expressed as tannic acid. Extraction done at $100^{\circ} \mathrm{C}$ for $30 \mathrm{~min}$

\begin{tabular}{lcc}
\hline \multirow{2}{*}{ Source of sample } & \multicolumn{2}{c}{ Tannin found (s by weighi) } \\
\cline { 2 - 3 } & Range & Average $^{\text {s }}$ \\
\hline Juana Diaz & $0.76-0.78$ & 0.77 \\
Lajas & $0.58-0.66$ & 0.62 \\
Mayagúez & $0.30-0.36$ & 0.34 \\
Ponce & $0.60-0.64$ & 0.63 \\
Yauco & $0.66-0.70$ & 0.68 \\
\hline
\end{tabular}

'Average of 3 determinations.

This range is approximately the same as that for white wine. Therefore, in terms of tannin content, mabí is quite similar to white wine.

Table 4 shows the crude protein content of the bark and its aqueous extract. Twenty-one to $43 \%$ of the crude protein in the bark was extracted at $100^{\circ} \mathrm{C}$. The crude protein of the extracts varied from 2.25 to $3.75 \%$. Since the bark contains non-protein nitrogen, for example nitrates and 
maybe some alkaloidal substances, not all of the nitrogen in the bark will be utilized by the fermenting organisms. The "pie" provides some metabolizable nitrogen in the form of lysed yeast cells and carry-over bark extract nitrogen. This, along with the metabolizable portion in the bark extract, serves adequately as nitrogen sources during the fermentation process.

Analysis of mabi samples gave a crude protein content of $0.28-0.35 \%$. The addition of $1.5 \%$ bark extract would provide $0.34-0.06 \%$ crude protein. On the basis of a range of $0.28-0.35 \%$ crude protein in mabí, the "pie" would contribute approximately $0.25-0.29 \%$ of the crude protein. Since the sugar contributes no protein, the major portion of the nitrogen is therefore derived from the "pie", and principally from the lysed yeast or bacteria.

Table 5 shows the mineral content of the bark extract, sugar and water. In the bark, the content of minerals was in the order: $\mathrm{K}>\mathrm{Ca}>\mathrm{Mg}>\mathrm{Fe}$ $>\mathrm{Na}>\mathrm{P}>\mathrm{Mn}$. The amounts extracted followed the same trend. However, the percentage of each element extracted by boiling the bark

T'ABLE 4.-Protein content of bark and of aqueous extract of bark of mabi. Extraction done at $100^{\circ} \mathrm{C}$ for $30 \mathrm{~min}$

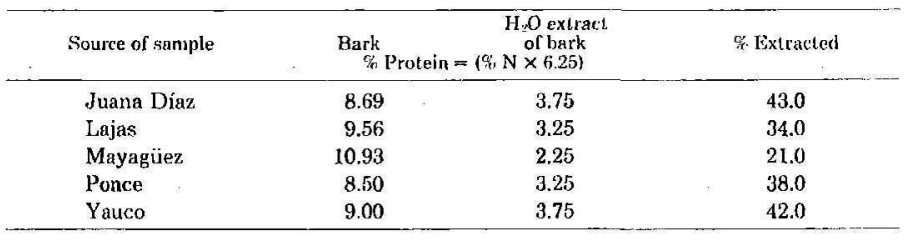

for $30 \mathrm{~min}$ showed no consistent trend, varying with the source of the bark. The only consistent aspects were the high extractability of potassium $(63-80 \%)$ and the very low extractability of calcium, which was present perhaps in an insoluble bound form in the plant tissue.

Very small amounts of sodium and manganese were found in all the samples examined. Compared with other samples, a relatively high level of iron was detected in the extract of the bark collected in Mayagüez. This could have been due to the storage conditions of the bark, a factor which could have also been responsible for the apparent lack of a consistent trend in the amounts of minerals encountered in the samples.

All of the minerals found in the bark, except phosphorus, were detected in the sugar also, but at lower levels. Tap water contained $\mathrm{Ca}, \mathrm{Mg}, \mathrm{K}$ and $\mathrm{Na}$ but not $\mathrm{P}, \mathrm{Fe}$, nor $\mathrm{Mn}$. Recognizing that the "pie" also contained some of all the minerals assayed for, it may be concluded that all the mabí ingredients contributed to the mineral nutrition of the fermenting organisms. Moreover, since no mineral supplements were added to the mixture and the final nroduct was acceptable, it must be concluded that 
the overall mineral content of the mixture was adequate for the microbial activity during fermentation.

Table 2 shows the alcohol, sugar and acid contents of mabi prepared by the conventional method and by controlled fermentation. Overall, mabi prepared by the two methods was quite similar, except in the case of volatile acidity, a higher amount of which was detected in the mabi prepared by the conventional method. Apparently, this was due to the greater production of acetic acid, since more of it was detected in the conventional sample. Possibly, the proportion of bacteria to yeast in the conventional sample was greater than in the controlled fermentation sample, and since acetic acid is a bacterial fermentation product, this larger amount probably explains the observed differences.

TABLE 5.- Minerals in mabi bark, mabi bark extract, unrefined sugar and tap waler (average percent by weight of 3 different determinations)'

\begin{tabular}{|c|c|c|c|c|c|c|c|c|}
\hline Sample & Source & $P$ & $\mathrm{Ca}$ & $\mathrm{Mg}$ & K & $\mathrm{Fe}$ & $\mathrm{Mn}$ & $\mathrm{Na}$ \\
\hline \multirow[t]{6}{*}{ Bark } & Juana Diaz & $" 0.027^{1}$ & 2.20 & 0.27 & 0.63 & 0.12 & 0.014 & 0.04 \\
\hline & & 10.011 & 0.13 & 0.10 & 0.48 & 0.08 & 0.005 & 0.02 \\
\hline & & $49 \%$ & $6 \%$ & $37 \%$ & $76 \%$ & $67 \%$ & $36 \%$ & $50^{\circ}$ \\
\hline & Lajas & 0.033 & 1.50 & 0.22 & 0.28 & 0.18 & 0.010 & 0.05 \\
\hline & & 0.017 & 0.11 & 0.10 & 0.22 & 0.02 & 0.004 & 0.03 \\
\hline & & $52 \%$ & $7 \%$ & $45 \%$ & $79 \%$ & $11 \%$ & $40 \%$ & $60 \%$ \\
\hline \multirow[t]{9}{*}{. } & Mayàgüez & 0.026 & 2.60 & 0.25 & 0.88 & 0.48 & 0.034 & 0.02 \\
\hline & & 0.008 & 0.08 & 0.06 & 0.55 & 0.26 & 0.003 & 0.01 \\
\hline & & $31 \%$ & $3 \%$ & $24 \%$ & $63 \%$ & $54 \%$ & $9 \%$ & $50 \%$ \\
\hline & Ponce & 0.026 & 1.50 & 0.18 & 0.63 & 0.09 & 0.013 & 0.02 \\
\hline & & 0.012 & 0.19 & 0.10 & 0.55 & 0.03 & 0.009 & 0.01 \\
\hline & & $46 \%$ & $13 \%$ & $56 \%$ & $87 \%$ & $33 \%$ & $69 \%$ & $50 \%$ \\
\hline & Yauco & 0.022 & 1.9 & 0.23 & 0.69 & 0.08 & 0,013 & 0.04 \\
\hline & & 0.010 & 0.20 & 0.10 & 0.55 & 0.02 & 0.004 & 0.01 \\
\hline & & $45 \%$ & $11 \%$ & $43 \%$ & $80 \%$ & $25 \%$ & $31 \%$ & $25 \%$ \\
\hline Sugar & & 2 & 0.14 & 0.05 & 0.23 & 0.03 & 0.003 & 0.02 \\
\hline Water & & & 0.15 & 0.06 & 0.03 & 2. & 2 & 0.04 \\
\hline
\end{tabular}

'a, b. c. First values under each mineral is the amount of that mineral in the bark. Second value under each mineral is the amount of that mineral in aqueous extract. Third number under each mineral is the percentage of that mineral extracted from the bark by boiling for 30 minutes.

Not detectable.

Table 6 records the quantities of flavoring substances produced in mabí prepared by both methods. No diacetyl was detected in either sample. Soltero and Hernández-Mora (13) obtained similar results. Although all the other products appeared in both batches, the levels differed. Again, this probably reflects the difference in the bacteria to yeast ratio in the two samples since the inocula were not equalized. However, the results confirm that in both cases the same type of fermentation ensued. 
TABLe 6.-Flavoring substances in Mabi

\begin{tabular}{|c|c|c|c|c|}
\hline \multirow{3}{*}{ Flavoring substance } & \multicolumn{4}{|c|}{ Methor of preparing melbi } \\
\hline & \multicolumn{2}{|c|}{ Conventional. } & \multicolumn{2}{|c|}{ Controlled fermentation } \\
\hline & Range & Average & Range & Average \\
\hline Acetaldehyde & $2.5-3.9$ & 3.2 & $0.44-2.8$ & L.62 \\
\hline Methyl acetate & $0.11-0.16$ & 0.14 & $0.06-0.011$ & 0.09 \\
\hline Ethyl acetate & $0.65-0.73$ & 0.69 & $0.15-0.17$ & 0.16 \\
\hline Isoamyl alcohol & $0.23-0.27$ & 0.25 & $0.49-0.99$ & 0.74 \\
\hline Acetylmethylcarbinol & $28.0-32.0$ & 30.0 & $33.0-41.0$ & 37,0 \\
\hline Diacetyl & - & - & - & - \\
\hline
\end{tabular}

\section{RESUMEN}

Análisis químicos han demostrado que el extracto de la cáscara de mabí usado en la preparación de la bebida contiene de $6.1 \%$ a $16.1 \%$ de hidratos de carbono totales solubles y de $1.2 \%$ a $2.8 \%$ de azúcares reductores, un promedio de $0.34 \%$ a $0.77 \%$ de taninos y de $2.25 \%$ a $3.75 \%$ de proteínas brutas. El extracto de la cáscara contenía $\mathrm{P}, \mathrm{Ca}$, $\mathrm{Mg}, \mathrm{K}, \mathrm{Fe}, \mathrm{Mn}$, y $\mathrm{Na}$. El azúcar sin refinar contenía todos los minerales antes mencionados excepto $\mathrm{P}$, pero no se detectaron $\mathrm{Fe}, \mathrm{P}$ ni $\mathrm{Mn}$ en el agua utilizada. El "pie" o mabi fermentado contribuyen todos los ingredientes que se han mencionado previamente; especialmente la proteína. Se encontró que el mabí contenía de $2.8 \%$ a $3.2 \%$ de proteína.

El mabi fue preparado por el método convencional y también inoculando ingredientes esterilizados con una mezcla de Aerobacter aerogenes y Saccaromyces cerevisiae. En ambos tipos se encontraron las siguientes substancias: etanol, ácido láctico y ácido acético. Se encontró que los valores de $\mathrm{pH}$ finales fueron muy similares: 3.7 y 3.9 , respectivamente. También ambos tipos contenían las siguientes: acetaldehído, acetatos metílicos y etílicos, alcohol amílico y acetilmetilcarbinol. No se encontró diacetil en ambos tipos.

\section{LITERATURE CITED}

1. A.O.A.C., 1975. Official Methods of Analysis, 12th ed, Association of Official Analytical Chemists, Washington, D. C.

2. Dubois, M. Gilles, K. A. Hamilton, J. K. Rebers, P. A. and Smith, F, 1956. Colorimetric method for determination of sugars and related substances, Anal. Chem 28: 350-56.

3. Folin, $O$. and Denis $W ., 1915$. A colorimetric method for the determination of phenol (and phenol derivatives) in urine, J. Biol. Chem. 22: 305.

4. John, M. K., 1970. Colorimetric determination of phosphorus in soil and plant materials with ascorbic acid, Soil Sci. 109: 214-20.

5. Joslyn, M. A., 1970. Methods in Food Analysis, pp. 709-711. Academic Press, New York.

6. Kunkee, R. F, and Amerine, M. A., 1970. Yeast in wine-making. In The Yeasts, Vol, III, pp. 5-60, A. H. Rose and J. S. Harrison (Ed). Academic Press, New York. 
7. Landlyke, A. F., and Peterson, W. H., 1937. Determination of acetyimethylcarbinol. Ind. Fing. Chem. Anal. ed. 9: 163-66.

8. Manual de Métodos Analíticos de la Planta Piloto de Ron, 1969 pp. 15, 17, 21, 23, 27, 28, 29-30, 43-49, P.R., Esta. Fxp. Agric. Univ. P.R.

9. McClure, D. W., 1976. The Chemistry of Winemaking and Brewing, J. Chem, ed. 53: 70-73.

10. Montoya A. and Graham, H. D., 1981. Microbiological Studies of the Mabi Fermentation, J. Agric, Univ. P.R. 65 (3); 219-31.

11. Neish, A. C., 1952. Analytical Methods for Bacterial Fermentations, Regional Laboratory, Saskatoon, Saskatchewan, Canada. Rep. 46-8-3. 2nd., rev. ed, NRC No. 2952.

12. Prescott, S. C. and Dunn, C. G., 1959. Industrial Microbiology," pp. 40-51. McGraw Hill Book Co., Inc, New York.

13. Soltero, F. V. y Hernández, J., 1955. Estudios sobre la fermentación del mabí. Bimestrario del Colegio de Químicos de Puerto Rico, Hato Rey, Puerto Rico, 9 (5): 65-73,

14. Swann, M. H., 1949. Determination of dibasic acids in alkyct resins, Anal. Chem. 21: 1448-53. 